DOI: http://doi.org/10.22364/hssl.26.2.5

\title{
ERGONOMIC RISKS INFLUENCE ON WORKER'S WORK ABILITY AT METAL MANUFACTURING ORGANISATIONS
}

\section{Kristīne Bokše}

Mg. sc. soc.

\section{Henrijs Kalıịis}

Dr. sc. admin.

\section{Ženija Roja}

Dr. med.

\begin{abstract}
Manufacturing is one of the growing economy sectors in Latvia and the number of employees who are exposed to work environment risk, especially ergonomic risk, increases. Physical overload at work influences work abilities that can have negative effect on employee`s health and work task performance. The aim of the research was to find out ergonomic risk influence on workers work ability at manufacturing organisations in Latvia. In the research such methods as the checklist method as a questionnaire, Key Indicator Method for analysing ergonomics risks and work ability index determination were applied. Research results show that employees at metal manufacturing organisations mainly complain about overload at the workplaces, ergonomic risk-related health problems, but at the same time indicate their work abilities are good or excellent. Only those who have longer work experience have indicated their poor work ability. The physical load analysis results are in accordance with questionnaire results and employees are subjected to severe physical overload. Hence, ergonomic risks can have impact on workers work ability in longer term, as work related diseases could appear.
\end{abstract}

Keywords: Latvia, ergonomics, risk management, manufacturing, physical load, work ability, work environment

\section{Introduction}

In recent years, one of the largest and most developed sectors of the economy is manufacturing in Latvia. In general, the sector is experiencing stable growth; starting since 2015 it provided $17 \%$ of total manufacturing turnover and $21 \%$ of total exports of goods. The manufacturing industry provides 123.5 thousand jobs, which corresponds to $13.8 \%$ of the total number of employed in the country (Ondza, 2017). 
In recent years, a rapid increase is observed in the metalworking and mechanical engineering sub-sectors, where production volumes rose by 15-35\% (Abolins, 2018).

With the growth and industry development, the number of employees who are exposed to work environment risks increases. Hence, the risk analysis of the work environment at the sites becomes very significant, that will allow one to develop appropriate health and safety solutions and increase work ability (Lejins, 2016).

Work abilities are influenced by physical overload at work (lifting, moving heavy loads, repeated hand and arm movements, awkward postures, work with hands raised above shoulder level etc.) (Schneider, 2001; Jaffar, 2011). As a result, employees suffer from physical overload, fatigue, reduced concentration, causing various occupational diseases and accidents (Vanadzins, 2013).

By providing good ergonomic conditions at the workplaces, the work abilities and productivity can be increased and employees will be more motivated to work better (State Labour Inspection, 2017). At the same time, it will reduce the number of occupational diseases and related safety and health problems.

The term work ability is understood in this research as "occupational competence, the health required for the competence, and the occupational virtues that are required for managing the work tasks" a term that Finnish researchers coined in the 1980s as a response to what they perceived as an overemphasis on disability (Ilmarinen, 2006, 2009; Tengland, 2011).

It should be noted that not only work can reduce work abilities, it can also be influenced by factors outside the workplace, such as family relationships, friends, social life, as well as various personal aspects, age, health status, various addictions (alcohol, smoking) and, of course, physical fitness and physical activities (Ilmarinen, 2005).

Taking into account the fact that in Latvia increases in health problems caused by ergonomics risks at the workplaces, the research topic on how ergonomics risks influence work abilities is significant (Roja, 2018).

The aim of the research was to find out the ergonomic risk influence on workers work ability at manufacturing organisations in Latvia.

\section{Materials and Methods}

For the research were chosen a metal manufacturing organization with such departments: metal boards, metal constructions and painting departments. The manufacturing company employs 80 workers. Accordingly, the total number of respondents and considering the probability of errors, the number of respondents to which the results are considered reliable was 
calculated. With a $90 \%$ confidence level, at a margin of $5 \%$, the estimated minimum sample size is 62 respondents. In the survey participated 63 respondents. There are several departments in the company that analysed workplaces that could have increased workload.

In the research, workstations were chosen from three different departments: the metal boards department, the metal structure department and the painting department. In the metal boards department, the processes of assembly, packing and quality control were analysed, but in the metal structure department the assembly and quality control processes. The operations of the boards' sorting line were analysed in the painting department. The characteristics of involved research subjects are represented in Table 1.

Table 1. Background factors of the subjects: length of service, age, height, weight, body mass index (BMI)

\begin{tabular}{|c|c|c|c|c|c|c|}
\hline $\begin{array}{c}\text { Population } \\
\text { (length of service) }\end{array}$ & n & $\begin{array}{c}\text { Mean age } \\
\pm \text { SD }\end{array}$ & Range & $\begin{array}{l}\text { Mean height, } \\
\mathrm{cm} \pm \mathrm{SD}\end{array}$ & $\begin{array}{c}\text { Mean weight, } \\
\text { kg } \pm S D\end{array}$ & $\begin{array}{l}\text { Mean BMI, } \\
\mathrm{kg} / \mathrm{m}^{2} \pm \mathrm{SD}\end{array}$ \\
\hline $\begin{array}{l}\text { Metal boards } \\
\text { department }\end{array}$ & 25 & $31,3 \pm 8,1$ & $22-45$ & $1,70 \pm 0,07$ & $69,0 \pm 12,8$ & $23,9 \pm 3,3$ \\
\hline (0-5 years) & 14 & $32,3 \pm 10,3$ & $22-45$ & $1,73 \pm 0,06$ & $61,5 \pm 5,0$ & $20,5 \pm 2,5$ \\
\hline (6-15 years) & 11 & $29,5 \pm 2,3$ & $28-32$ & $1,67 \pm 0,08$ & $79,0 \pm 9,0$ & $28,3 \pm 2,7$ \\
\hline (> 16 years) & - & - & - & - & - & - \\
\hline $\begin{array}{c}\text { Metal construction } \\
\text { department }\end{array}$ & 27 & $32,9 \pm 10,7$ & $20-53$ & $1,73 \pm 0,06$ & $68,0 \pm 12,9$ & $22,7 \pm 3,4$ \\
\hline (0-5 years) & 23 & $32,7 \pm 11,6$ & $20-53$ & $1,68 \pm 0,05$ & $60,0 \pm 6,5$ & $21,3 \pm 2,8$ \\
\hline (6-15 years) & 5 & $34,0 \pm 5,7$ & $30-38$ & $1,70 \pm 0,04$ & $73,1 \pm 7,9$ & $25,3 \pm 3,0$ \\
\hline (> 16 years) & - & - & - & - & - & - \\
\hline $\begin{array}{c}\text { Painting } \\
\text { department }\end{array}$ & 11 & $33,4 \pm 8,1$ & $27-46$ & $1,69 \pm 0,06$ & $68,1 \pm 9,8$ & $23,8 \pm 3,1$ \\
\hline (0-5 years) & 5 & $37,5 \pm 5,5$ & $31-46$ & $1,66 \pm 0,07$ & $69,2 \pm 5,6$ & $25,1 \pm 2,5$ \\
\hline (6-15 years) & 6 & $27,5 \pm 2,3$ & $27-35$ & $1,68 \pm 0,04$ & $71,1 \pm 6,5$ & $25,2 \pm 2,8$ \\
\hline (> 16 years) & - & - & - & - & - & - \\
\hline
\end{tabular}

The body mass index was calculated using the formula weight/ height ${ }^{2}$ considering four BMI categories: underweight: BMI $\leq 19 \mathrm{~kg} / \mathrm{m}^{2}$, ideal weight: $19<\mathrm{BMI} \leq 25 \mathrm{~kg} / \mathrm{m}^{2}$, overweight: $25<\mathrm{BMI} \leq 30$, severe overweight: BMI $>30 \mathrm{~kg} / \mathrm{m}^{2}$ (Bhattacharya, 2007). 
In the research, the following methods were applied: The checklist method, Key Indicator method and work ability index evaluation.

The checklist method as questionnaire was conducted to find out the opinion of the workers on the condition of existing workplaces, complaints about workload, work organisation, as well as worker's opinion on work abilities. The results acquired were processed by applying statistical data processing program SPSS.20.

The Key Indicator Method for assessment of the manual handling of heavy loads developed by the German Federal Institution for Industrial Safety and Occupational Medicine was used to assess social care workers ergonomics risks (Steinberg, 2006). Key indicators (criteria) to be taken into account are: object mass rating points (M); the employee's posture rating points $(\mathrm{P})$; working conditions rating points (C); working time/intensity value points (I). Risk assessment is carried out by physical workload risk score (RS) using the following formula: $\mathrm{RS}=(\mathrm{M}+\mathrm{P}+\mathrm{C}) \times \mathrm{I}$. According to this method work hardness categories (or risk range) are: I - light work or low load situation (RS $<10$ ); II - moderate work or increased load situation (RS $=10 \ldots 25)$; III - hard work or highly increased load situation ( $R S=25 \ldots 50$ ); IV - very hard work or physical overload ( $\mathrm{RS}>50$ ).

The work ability evaluation was done through the Work Ability Index (WAI) developed by Finnish researchers and based on workers' selfperception (Tuomi, 1998; Ilmarinen 2009). It is composed of seven items: current work ability compared with the life time best, work ability in relation to job demands, number of current diseases diagnosed by a physician, estimated work impairment due to diseases, sick leave during the past year (12 months), own prognosis of work ability two years from now and mental resources. The final score varies from 7 to 49 points, distributed across the following categories: poor (7...27), moderate (28...36), good (37 ...43) and excellent work ability (44...49).

\section{Results and Discussion}

In total, 63 employees were involved in the questionnaire, 42 of them women and 21 men. Most of the workers (26 employees) were in the age group of 26-35 years, followed by employees in the age group of 36-50 (18 employees) and 15 employees who rank in the 18-25 age group. The staff noted that the arms, legs, back (46 employees) are the mostly affected during the working process, followed by wrists and fingers (22 employees), arms and legs (See Figure 1). 


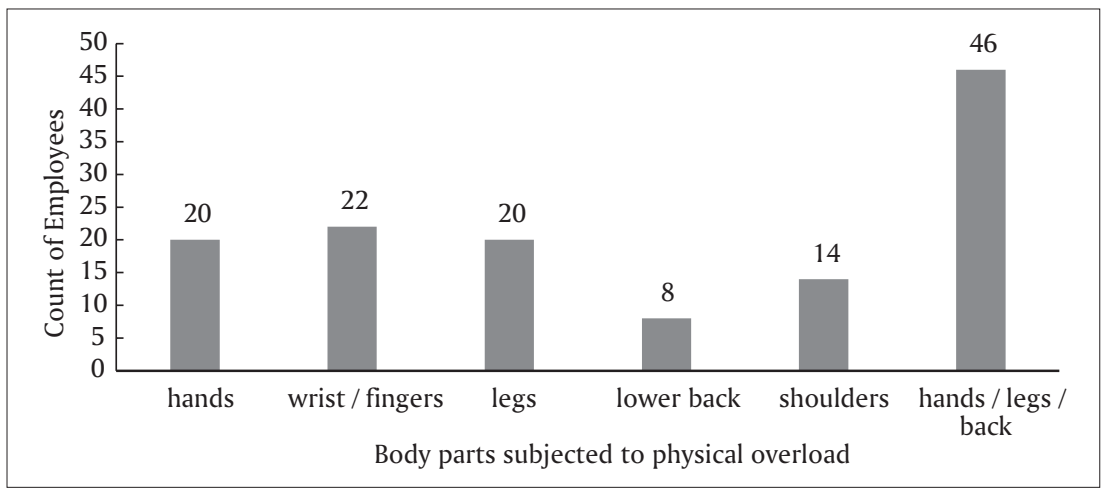

Figure 1. Employee`s opinion on body parts subjected to physical overload

The results show that workers mainly complain about pain in different parts of the body. The largest number of employees complained of pain in the back (65\% of all respondents), in hands (46\% of all respondents) and in legs ( $21 \%$ of all respondents). The results are shown in Figure 2.

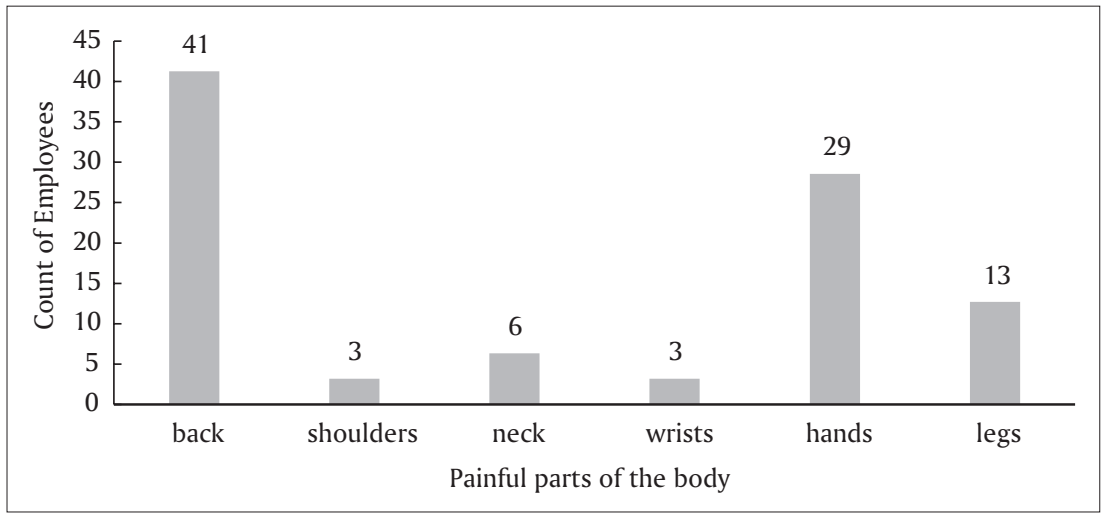

Figure 2. Employee`s opinion on painful parts of body

Comparing the obtained results with the lifting weights, it can be concluded that the employees most often carry loads in the range of $5-10 \mathrm{~kg}$ (29 respondents), followed by a lifting weight of $10-15 \mathrm{~kg}$, as indicated by 17 respondents, and even sometimes during the work process it is necessary to move and carry load in the range of $15-25 \mathrm{~kg}$ (marked by $8 \%$ of all respondents). 
In order to analyse the ergonomics risks in metal boards department, metal construction department and painting department regarding moving and lifting of physical load, the Key Indicator Method was applied. According to Key indicator method score for total workload was calculated and such parameters were considered: workload, value points dependent on the weight of load to be moved, value points dependent on position of the body during performance of operations, value points dependent on working conditions, value points dependent on the length of work shift. The results are shown in Table 2.

Table 2. Key Indicator Method risk degree for human factor analysis regarding lifting and moving physical load (L-load weight, P-work posture, C-work conditions, I-work intensity), standard deviation (SD), Work load score $(\mathrm{WL})$, risk degree $\left(\mathbf{R}_{\mathrm{d}}\right)$

\begin{tabular}{|c|c|c|c|c|c|c|}
\hline & $\mathrm{L} \pm \mathrm{SD}$ & $\mathrm{P} \pm \mathrm{SD}$ & $\mathrm{C} \pm \mathrm{SD}$ & $\mathrm{I} \pm \mathrm{SD}$ & WL & \multirow{2}{*}{$\begin{array}{c}\text { Risk } \\
\text { degree } R \\
\text { I-V }\end{array}$} \\
\hline & \multicolumn{5}{|c|}{ Number of points } & \\
\hline \multicolumn{7}{|c|}{ Metal boards department $(n=25)$} \\
\hline $\begin{array}{c}\text { Metal board } \\
\text { operators }(n=6)\end{array}$ & $2.7 \pm 1.3$ & $4.2 \pm 1.5$ & $0.9 \pm 0.5$ & $8.0 \pm 1.3$ & 62.40 & IV \\
\hline $\begin{array}{c}\text { Metal board } \\
\text { quality control } \\
\text { operators }(n=7)\end{array}$ & $2.3 \pm 1.6$ & $4.4 \pm 1.3$ & $0.9 \pm 0.6$ & $7.8 \pm 1.2$ & 59.28 & IV \\
\hline $\begin{array}{c}\text { Metal board } \\
\text { packing operators } \\
(n=12)\end{array}$ & $2.5 \pm 1.5$ & $4.1 \pm 1.1$ & $0.8 \pm 0.5$ & $7.2 \pm 1.7$ & 53.28 & IV \\
\hline \multicolumn{7}{|c|}{ Metal construction department $(n=27)$} \\
\hline $\begin{array}{l}\text { Metal construction } \\
\text { operators }(n=13)\end{array}$ & $3.9 \pm 2.1$ & $3.5 \pm 1.5$ & $0.9 \pm 0.4$ & $7.4 \pm 1.3$ & 61.42 & IV \\
\hline $\begin{array}{c}\text { Metal construction } \\
\text { quality control } \\
\text { operators }(n=14)\end{array}$ & $3.4 \pm 2.1$ & $3.2 \pm 1.7$ & $0.7 \pm 0.6$ & $6.2 \pm 1.0$ & 45.26 & III \\
\hline \multicolumn{7}{|c|}{ Painting department $(n=11)$} \\
\hline $\begin{array}{l}\text { Painting operators } \\
\quad(n=11)\end{array}$ & $2.1 \pm 1.2$ & $3.2 \pm 1.5$ & $1.0 \pm 0.8$ & $2.6 \pm 2.0$ & 16.38 & II \\
\hline
\end{tabular}

Analysing the physical workload in metal boards, metal construction and painting departments during lifting or moving heavy loads, the metal board operators, metal board quality control operators, metal board packing operators and metal construction operators are exposed to a most 
severe physical overload, what corresponds with the risk degree IV. Metal construction quality control operators fall into risk degree category III. Accordingly, to the methodology, the workload in these occupations is an endangerment to the workers' health. For this reason, special attention must be paid to necessary preventive measures in order to allow fatigued muscle groups to relax and further, a more detailed investigation of physical load is necessary. Painting operators fall within risk degree category II (moderate work), where their workload with respect to lifting of heavy loads is appropriate and slight improvements are necessary.

To find out the ergonomics risk influence on work abilities of the workers in metal boards department, metal construction department and painting department, an analysis of work ability index (WAI) was carried out. The WAI questionnaire was filled out. In total, 63 employees were interviewed, 42 of them women and 21 men. Mainly workers evaluate their work abilities as good and excellent, only some indicate poor and moderate work abilities. The results are provided in Figure 3.

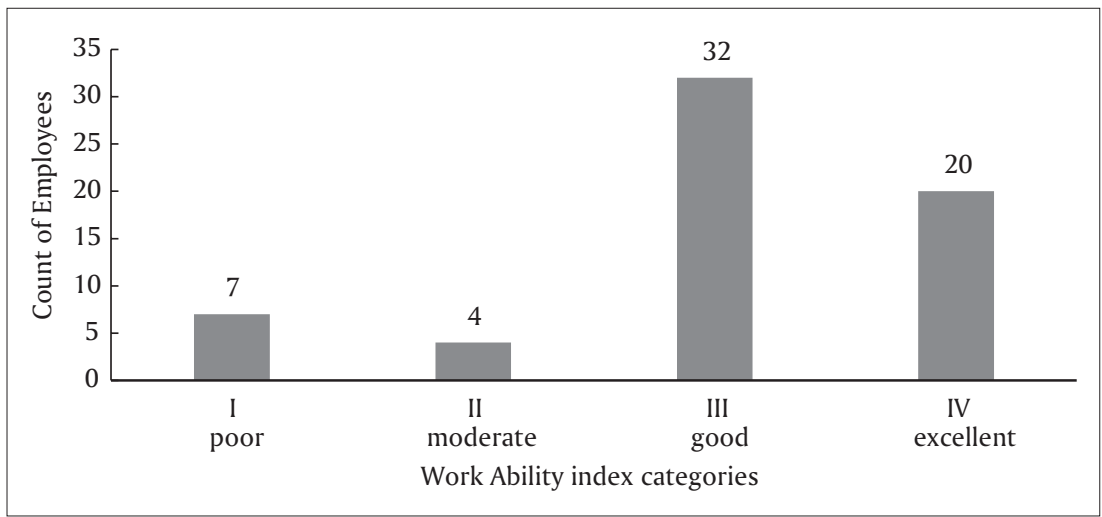

Figure 3. Count of the employees and Work Ability index categories

By overall work ability analysis, half of the employees have good work abilities and rank in Category III accordingly to work ability index, but $32 \%$ of respondents indicated that they have excellent work abilities (Category IV). It should be noted that 7 respondents indicated that they have poor working ability (category I). Total work ability evaluation is shown in Table 3. 
Table 3. Work Ability Index (WAI) results $(n=63)$

\begin{tabular}{|c|c|c|c|}
\hline WAI & Scores & $\begin{array}{l}\text { Rating } \\
\text { scores }\end{array}$ & $\begin{array}{c}\text { Employees view/ } \\
\text { Expert view }\end{array}$ \\
\hline \multicolumn{4}{|c|}{ Metal boards department $(n=25)$} \\
\hline Metal board operators $(n=6)$ & $7 \ldots 49$ & $43.2 \pm 5.4$ & $41 / 33$ \\
\hline $\begin{array}{l}\text { Metal board quality control operators } \\
\qquad(n=7)\end{array}$ & $7 \ldots 49$ & $42.0 \pm 4.9$ & $40 / 38$ \\
\hline Metal board packing operators $(n=12)$ & $7 \ldots 49$ & $35.8 \pm 6.5$ & $37 / 35$ \\
\hline \multicolumn{4}{|c|}{ Metal construction department $(n=27)$} \\
\hline Metal construction operators $(n=13)$ & $7 \ldots 49$ & $37.5 \pm 5.1$ & $38 / 35$ \\
\hline $\begin{array}{c}\text { Metal construction quality control } \\
\text { operators }(n=14)\end{array}$ & $7 \ldots 49$ & $38.3 \pm 4.3$ & $39 / 35$ \\
\hline \multicolumn{4}{|c|}{ Painting department $(n=11)$} \\
\hline Painting operators $(n=11)$ & $7 \ldots 49$ & $39.6 \pm 3.6$ & $40 / 37$ \\
\hline
\end{tabular}

Deeper analysis of work ability was carried out accordingly WAI methodology. When comparing existing work-related physical and mental workloads (scale 1-5), workers noticed that their work ability ranges from medium to very good. Most believe that their work capacity is good, as is indicated by $44 \%$ of respondents. The same is true of the mental workload, which means that the majority ( $57 \%$ of respondents) believe that they have good work abilities. The average score is $4 \pm 1$, which corresponds to good work ability.

As it can be seen in the Figure 4, the majority of the workers have not had any illness in the last 5 years (32\% of respondents). One and two diseases were indicated accordingly by $24 \%$ and $19 \%$ respondents. Workers, who had 5 or more illnesses, correspond to $5 \%$ of the respondents. The most common illnesses among workers are influenza; it is indicated by $33 \%$ of respondents, followed by colds, angina, etc. diseases. It can be concluded that special attention should be paid to the microclimatic parameters of the workplace - temperature, air velocity rate, air humidity, since $50 \%$ of respondents indicated complaints on microclimate and also point out angina as main disease at the workplace.

The subjective assessment of work ability reveals that the score obtained is in the range of 4 to 6 (the assessment scale is in the range of 1 to 6 ), where $49 \%$ of respondents have indicated that they have no incapacity for work due to illness. 30\% of respondents indicated that the incapacity is very rare ( 2 to 3 times a year) and minority (21\%) indicated that the incapacity is 3 to 6 times a year. 


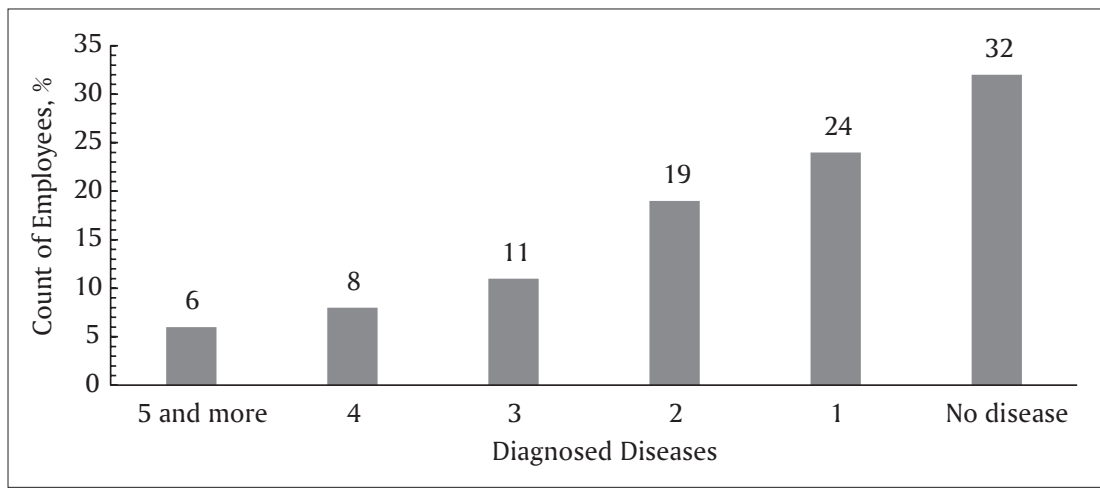

Figure 4. Count of the employees and diagnosed diseases in the last 5 years

The results show that $32 \%$ of the respondents are delayed from work for 1 to 9 days due to illness, as well as another 32\% had delays of 10 to 24 days. There was no delay at all for $24 \%$ of employees. For people who have been absent for work, the main reasons were cold, flu, respiratory infections, back pain and knee pain. The cause of the diseases could be the inadequate microclimate, dry air causing airways inflammation, as well as inappropriate air velocity, resulting in cold. In addition to this, it was found that workers are delayed because of both back pain and knee pain. This could be due to the fact that work should be done while standing, as well as the inadequate gravity of being crippled (back pain). Therefore, attention should be paid to both the characteristics of the process and the working environment conditions. Number of days delayed due to illness is shown in Figure 5.

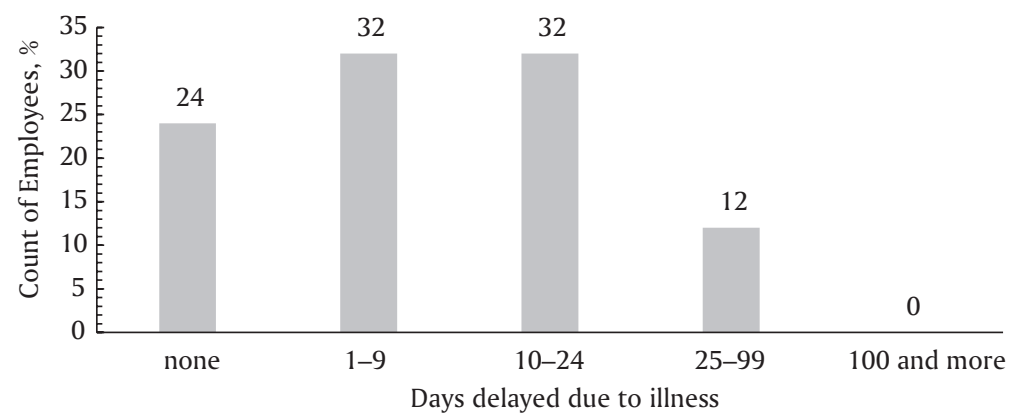

Figure 5. Count of the employees and days delayed due to illness 
Most workers admit they are confident to be able to work and work conditions will improve in the future, as indicated by $87 \%$ of the respondents. $5 \%$ of respondents have indicated they are not sure if they will be able to work, while $8 \%$ have indicated that they will be able to work certainly in future. Hence, a deeper analysis is necessary to find out which employees are delaying work due to various illnesses and may need to change work tasks in order to relieve the current workload.

Analysis of WAI section about workload influence on work abilities concludes that the majority of respondents (56\%) consider that their work is not heavy and working conditions are very good. A moderate load was indicated by $44 \%$ respondents. The mutual relations in the company are measured, as medium and good and internal collaboration among colleagues is very good. It can be evaluated as positive sign in the organisation, but such results can be also misleading. That could be explained by employees fear of unemployment and employees perhaps do not reveal the real condition of their health and work ability; hence, the ergonomics risk influence on work ability in real work conditions is higher than opinion of the employees. It is also in accordance with other research and existing intervention research suggests that workplace conditions can influence work ability, for example, musculoskeletal disorders risk factors (Chaisson, 2015), stress at work (Habibi, 2014), mental workload, shift work (Safari, 2013), vibration (Gerhardsson and Hagberg, 2014) etc. Interventions designed to improve health and lifestyle behaviour (Pohjonen and Ranta, 2001) and job restructuring (Marqueze, 2008) are associated with higher work ability. The research will continue to elaborate concrete interventions to minimize ergonomic risks and improve work ability at the workplaces in the metal manufacturing organisation.

\section{Conclusions}

Research results reveal that employees at the metal manufacturing organisation mainly complain about overload at the workplaces, ergonomic risk-related health problems at the work, especially of pain in the upper back and lower back, as well as pain in the hands and wrists. The physical load analysis proved the questionnaire results that employees are subjected to severe physical overload, excluding painting operators, who fall within moderate work risk degree category. At the same time, employees consider their work ability as good and very good, as indicated by $83 \%$ of respondents. Those who have longer work experience, both in company and in general, have indicated their poor work ability. This can be explained as they have a variety of work related illnesses that are delayed for a long time, as well as employee's fear of unemployment if they reveal 
real opinion on work conditions. Hence, ergonomic risks can have impact on workers work ability in longer term, as work related diseases could appear.

\section{REFERENCES}

1. Bhattacharya, S., Campbell, D. M., Liston, W. A., Bhattacharya S. (2007). "Effect of Body Mass Index on pregnancy outcomes in nulliparous women delivering singleton babies," BMC Public Health, Vol. 7, article 168.

2. Chiasson, M. I., Imbeau, D., Major, I., Delisle, A. (2015). Influence of musculoskeletal pain on workers' ergonomic risk-factor assessments. Applied Ergonomics 49.

3. Gerhardsson, L., Hagberg, M. (2014). Work ability in vibration-exposed workers. Occupational Medicine, Vol. 64, Issue 8, pp. 629-634.

4. Habibi, E., Dehghan, H., Safari, S., Mahaki, B., Hassanzadeh, A. (2014). Effects of work-related stress on work ability index among refinery workers 3: 18 .

5. Ilmarinen, J. (2005), Towards a longer worklife. Finnish Institute of Occupational Health. Helsinki: p. 420.

6. Ilmarinen, J. (2006). The ageing workforce-Challenges for occupational health. Occupational Medicine, 56, pp. 362-364.

7. Ilmarinen, J. (2009). Work ability: a comprehensive concept for occupational health research and prevention. Scandinavian Journal of Work Environ Health, 35(1), pp. 1-5.

8. Ilmarinen, J. (2009). Work ability-A comprehensive concept for occupational health research and prevention. Scandinavian Journal of Work Environment \& Health, $35,1-5$.

9. Jaffar, N., Abdul-Tharim, A. H., Mohd-Kamar, I. F., Lop, N. S. (2011). A literature review of ergonomics risk factors in construction industry. Procedia Eng. 20, pp. 89-97.

10. Lejins, A. (2016). Information material for career guidance in the metalworking and mechanical engineering sector. Riga, p. 39 (In Latvian).

11. Marqueze, E. C., Voltz, G. P., Borges, F. N., Moreno, C. R. (2008). A 2-year follow-up study of work ability among college educators. Applied Ergonomics, 39, pp. 640-645.

12. Pohjonen, T., Ranta, R. (2001). Effects of worksite physical exercise intervention on physical fitness, perceived health status, and work ability among home care workers: Five-year follow-up. Preventive Medicine, 32, pp. 465-475.

13. Roja, Z., Kalkis, H., Roja, I., Zalkalns, J. (2018). Work Related Musculoskeletal Disorders (WRMSD) in Construction Workers and Main Causes. In: Goonetilleke, R., Karwowski, W. (eds.) Advances in Physical Ergonomics and Human Factors. AHFE 2017. Advances in Intelligent Systems and Computing, Vol. 602, pp. 27-286.

14. Safari, S., Akbari, J., Kazemi, M., Mououdi, M. A., Mahaki, B. (2013). Personnel's Health Surveillance at Work: Effect of Age, Body Mass Index, and Shift Work on Mental Workload and Work Ability Index. Journal of Environmental and Public Health Volume 2013, p. 6.

15. Schneider, S. P. (2001). Musculoskeletal injuries in construction: a review of the literature. Applied Occupational and Environmental Hygiene. 16, pp. 1056-1064. 
16. State Labour Inspection (2017). Latvia, Annual report 2016, p. 44.

17. Steinberg, U., Caffier, G., Liebers, F. (2006). Assessment of Manual Material Handling based on Key Indicators - German Guidelines in: Handbook of Standards in Ergonomics and Human Factors. Ed. by W. Karwowski. Lawrenz Erlbaum Associates. Mahwah, New Jersey, London, pp. 319-338.

18. Tengland, P. The concept of work ability (2011). Journal of Occupational Rehabilitation, 21, pp. 275-285.

19. Tuomi, K., Ilmarinen, J., Jahkola, A., Katajarinne, L., Tulkki, A. (1998). Work Ability Index, $2^{\text {nd }}$ revised edn. Helsinki: Finnish Institute of Occupational Health.

20. Vanadzins, I., Martinsone, Z., Lakisa, S., Reste, J., Gravele, M., Bake, M. A., Sprudza, D., Martinsone, I., Eglite, M. (2013). Working conditions and risks in Latvia, 2012-2013. Riga: SIA “TNS Latvia” Riga Stradins University Agency "Labor Safety and Environmental Health Institute”. p. 131 (In Latvian).

21. Abolins, M. (2018). One of the fastest growing sectors in Latvia is the manufacturing industry. Day Business. http://www.db.lv/zinas/viena-no-straujak-augosajam-nozarelatvija-apstrades-rupnieciba-473641 (In Latvian accessed on $27^{\text {th }}$ of June, 2018).

22. Ondza, D. (2017) Latvian Manufacturing Industry - Development, Challenges and Potential. Ministry of Finance.

http://www.fm.gov.lv/lv/aktualitates/jaunumi/fm_ekspertu_viedokli/55278-latvijasapstrades-rupnieciba-attistiba-izaicinajumi-un-potencials (In Latvian, accessed on $23^{\text {rd }}$ of June, 2018). 